\title{
JEKK
}

\section{Pengaruh Riwayat Komorbid Dan Pengetahuan Tentang Penyakit COVID-19 Terhadap Praktik 5M Pada Masyarakat Madiun Tahun 2020}

\author{
Puri Ratna Kartini", Arum Suproborini*, Yovita Aprilia Putri* \\ *Program Studi Farmasi, Fakultas Ilmu Kesehatan Dan Sains, Universitas PGRI Madiun
}

\begin{abstract}
Background: COVID-19 has become a health problem in the world, including in Indonesia. The high number of COVID-19 transmissions in Indonesia shows the need for massive prevention efforts. In addition to vaccination, the $5 \mathrm{M}$ health protocol is an effective way to reduce the number of COVID-19 transmissions. The implementation of the 5M program is influenced by several factors, including knowledge about COVID-19 and history of comorbidities.

Methods: This study is an observational-analytic study that aims to analyze the influence of comorbid history during last 3 months and knowledge aobut COVID-19 disease on 5M practice in the Madiun community. 5M practices in this research include wearing masks, washing hands, maintaining distance, avoiding crowds and maintaining immunity. The research design used in this study was cross sectional with the sampling technique used was purposive sampling. Data was obtained by distributing online questionnaires to people living in the Madiun area. The population in this study is the people of Madiun, and the sample in this study is the people of Madiun who voluntarily fill out online questionnaire. The study was carried out for 7 months, starting from June to December 2020.
\end{abstract}

Result: From the results of the Chi square test, it was concluded that the comorbid history and the knowledge about COVID-19 have an effect on 5M practice (comorbid history $\mathrm{p}=0.001$ and knowledge about COVID-19 $\mathrm{p}=0.000$ ).

Conclusion : The results of this study are expected to be an input for the government in determining policies to prevent COVID-19, especially in the Madiun area.

Keywords: COVID-19; Comorbid; Knowledge; Madiun; 5M.

*Penulis korespondensi: puri@unipma.ac.id 


\section{Pendahuluan}

Corona virus Disease 2019 (COVID-19) saat ini tengah menjadi masalah kesehatan di dunia termasuk di Indonesia. Tercatat kasus baru COVID-19 di Indonesia mengalami peningkatan yang sangat signifikan sejak kasus pertama masuk pada bulan Maret 2020 hingga 30 Agustus 2020, yaitu sebanyak 51.952 kasus ${ }^{1}$. Peningkatan kasus yang terus berlangsung menunjukkan perlu adanya upaya pencegahan yang massif. Pemerintah diantaranya telah mencanangkan vaksinasi massal dan protokol kesehatan yaitu 5M sebagai upaya pencegahan penularan COVID19. 5M merupakan singkatan dari memakai masker, mencuci tangan, menjaga jarak, menghindari kerumunan dan menjaga imunitas. Kepatuhan masyarakat dalam mempraktikan $5 \mathrm{M}$ menjadi salah satu syarat untuk menurunkan angka kejadian COVID-19 di Indonesia. Dengan demikian perlu kiranya untuk memperhatikan faktor-faktor yang mempengaruhi kepatuhan masyarakat dalam mempraktikan 5M sehingga angka kejadian COVID-19 di Indonesia dapat diturunkan.

Moudy (2020) dalam penelitiannya menemukan bahwa usaha pencegahan COVID19 dipengaruhi oleh pengetahuan masyarakat. Pemberian pengetahuan yang spesifik, valid, dan tepat sasaran dapat meningkatkan perilaku masyarakat dalam usaha pencegahan penularan infeksi COVID-19². Pengetahuan merupakan salah satu domain dari perilaku kesehatan. Menurut B. Bloom, terdapat tiga domain/ranah dari perilaku, yaitu pengetahuan (knowledge), sikap (attitude), dan tindakan (practice). Banyak penelitian yang telah membuktikan pengaruh faktor pengetahuan terhadap perilaku kesehatan (termasuk didalamnya perilaku pencegahan) ${ }^{3}$. Rahmi (2021) dalam penelitiannya menemukan bahwa terdapat hubungan antara pengetahuan dengan kepatuhan protokol kesehatan 5M pada masyarakat di Kelurahan Kuin Utara Banjarmasin Utara dengan nilai p 0,017 ${ }^{4}$. Sejalan dengan penelitian tersebut, Iit dkk (2021) dalam penelitiannya kepada lansia melati di wilayah kerja puskesmas kampung Bali menemukan bahwa ada hubungan antara pengetahuan dengan perilaku lansia terhadap pencegahan penularan COVID-19 ${ }^{5}$.
Menurut L. Green, perilaku kesehatan dipengaruhi dan ditentukan oleh tiga faktor yaitu faktor predisposisi (predisposing factor), faktor pemungkin (enabling factor), dan faktor pendorong/penguat (reinforcing factor). Faktor predisposisi merupakan faktor yang berasal dari diri seseorang itu sendiri atau kecenderungan seseorang untuk menerima atau menolak suatu perilaku berdasarkan pengalaman dan norma yang dimilikinya, misalnya sosio demografi seperti perbedaan umur, jenis kelamin, pendidikan, pekerjaan, latar belakang pendidikan/pekerjaan serta daerah asal. Enabling factor meliputi keterampilan dan sumber daya yang perlu untuk melakukan perilaku kesehatan. Mencakup biaya, jarak, dan ketersediaan transportasi. Dan reinforcing factor meliputi sikap dan perilaku petugas kesehatan, tokoh masyarakat, tokoh agama, orang tua atau petugas lain yang merupakan kelompok referensi dari perilaku masyarakat ${ }^{3}$.

Selain sosio demografi, riwayat penyakit penyerta/komorbid pada diri seseorang juga merupakan faktor predisposisi yang dapat mempengaruhi kecenderungan seseorang tersebut untuk patuh terhadap protokol kesehatan. Banyak riset telah membuktikan adanya pengaruh yang kuat antara keberadaan penyakit komorbid yang diderita dengan angka kematian pada pasien COVID-19. Tim Pakar Satgas Penanganan COVID-19 telah melakukan analisis kematian pasien COVID19 berdasarkan usia dan riwayat komorbid atau penyakit penyerta. Hasil analisis tim pakar selama 5 bulan terakhir, berdasarkan aspek usia, pasien yang berada di usia 31 - 45 tahun berisiko masing-masing sebesar 2,4 kali lipat pada kematian. Dan yang berada di rentan usia 46 - 59 tahun, berisiko 8,5 kali lipat pada kematian ${ }^{1}$. Osibogun et al (2021) menemukan tingkat kematian pada proporsi pasien COVID19 dengan penyakit penyerta yang lebih tinggi secara signifikan sebesar 3,3\% dan dibandingkan dengan pasien COVID-19 yang tidak memiliki penyakit penyerta. Dalam penelitian tersebut lebih lanjut juga dijelaskan bahwa komorbiditas yang memprediksi kematian pasien COVID-19 tersebut antara lain hipertensi (OR: 2,21, 95\% CI: 1,22-4,01), diabetes (OR: 3,69, 95\% CI: 1,99-6,85), 
penyakit ginjal (OR: 12,53, 95\%CI: 1,97 79,56), kanker (OR: 14.12, 95\% CI: 2.0398.19) dan HIV (OR: 1.77-84.15) ${ }^{6}$. Lestari dan Ichsan (2021) dalam penelitiannya menemukan bahwa DM tipe 2 meningkatkan risiko keparahan $(\mathrm{OR}=1,15 ; 95 \% \mathrm{CI}=1,11-2,15$; $\mathrm{p}=0,004)$ dan meningkatkan risiko kematian $(\mathrm{OR}=1,65 ; 95 \% \mathrm{CI}=1,27-2,16 ; \mathrm{p}<0,001)$ pada pasien COVID-19 ${ }^{6}$.

Besarnya risiko kematian pada pasien COVID-19 dengan riwayat komorbid tersebut mempengaruhi tingkat kecemasan pasien dalam menghadapai pandemi, dimana tingkat kecemasan tersebut dapat memotivasi pasien untuk lebih mematuhi protokol kesehatan. Sehingga seseorang yang memiliki penyakit komorbid seperti hipertensi, diabetes, penyakit ginjal, kanker, HIV, dll akan cenderung untuk mematuhi protokol kesehatan dalam rangka mencegah dirinya tertular COVID-19 dibandingkan dengan seseorang yang tanpa riwayat komorbid. Pada penelitian yang dilakukan oleh Tobing dan Wulandari (2021) kepada lansia dengan penyakit komorbid seperti jantung, hipertensi dan DM di Kecamatan Parongpong Bandung Barat, hasil yang diperoleh adalah tingkat kecemasan yang dialami oleh lansia dengan penyakit penyerta/komorbid adalah berat sekali dengan skala tingkat kecemasan 30.35. Lebih lanjut, dijelaskan dalam penelitian tersebut bahwa lansia penderita hipertensi mengalami tingkat kecemasan berat sekali dengan skala tingkat kecemasan 31.43, lansia penderita penyakit jantung mengalami tingkat kecemasan berat dengan skala tingkat kecemasan 29.41, dan lansia penderita penyakit DM mengalami tingkat kecemasan berat dengan skala tingkat kecemasan $29.67^{7}$.

Kota Madiun merupakan wilayah administratif tingkat II di Jawa Timur yang menjadi kota pertama dengan status zona hijau di Jawa Timur pada tahun 2020. Hal ini karena selama beberapa pekan tidak terdapat kasus baru COVID-19 di wilayah Kota Madiun. Predikat ini menunjukkan adanya kemungkinan bahwa masyarakat di Kota Madiun patuh terhadap protokol kesehatan sebagai bentuk dari upaya pencegahan COVID-19, sehingga angka penularan COVID-19 di kota ini dapat diturunkan.
Beberapa faktor yang mempengaruhi kepatuhan masyarakat di Madiun terhadap protokol kesehatan perlu untuk dianalisis guna ditingkatkan lagi sehingga status zona hijau dapat terus dipertahankan. Faktor tersebut misalnya pengetahuan masyarakat tentang penyakit COVID-19 dan riwayat penyakit penyerta/komorbid.

Penelitian tentang pengaruh riwayat penyakit penyerta/komorbid terhadap kepatuhan masyarakat dalam melaksanakan protokol kesehatan $(5 \mathrm{M})$ pada masyarakat Madiun belum pernah dilakukan sebelumnya. Selain itu pengetahuan yang baik tentang penyakit COVID-19 merupakan hal mendasar yang harus dimiliki oleh masyarakat dalam melindungi dirinya dari penularan COVID-19. Sehingga hal inilah yang menjadi dasar tujuan dilaksanakannya penelitian ini. Dan dari hasil penelitian ini diharapkan dapat menjadi masukan bagi pemerintah dalam menetapkan kebijakan untuk menurunkan risiko penularan COVID-19 di Indonesia terutama pada masyarakat dengan penyakit penyerta.

\section{Metode}

Penelitian ini merupakan penelitian observasional analitik dengan desain penelitian cross sectional yang dilaksanakan mulai bulan Juni-Desember 2020. Penelitian ini dilakukan secara online kepada masyarakat yang tinggal di Kota Madiun dan Kabupaten Madiun. Berdasarkan data yang diperoleh dari Badan Pusat Statistik Kota Madiun dan Kabupaten Madiun per Maret tahun 2020, penduduk Kota Madiun yaitu sebesar 210.245 jiwa dan penduduk Kabupaten Madiun sebesar 744.350 jiwa. Teknik pengambilan sampel yang digunakan dalam penelitian ini adalah purposive sampling dengan pertimbangan luasnya cakupan wilayah penelitian, dan di saat yang bersamaan sedang dilaksanakan PPKM lokal sehingga tidak memungkinkan bagi peneliti untuk melakukan wawancara secara langsung kepada responden. Besar sampel ditentukan dengan menggunakan rumus slovin:

$$
n=\frac{\mathrm{N}}{1+\mathrm{Ne}^{2}}
$$


Dimana:

$$
\begin{aligned}
\mathrm{n}= & \text { Besar sampel } \\
\mathrm{N}= & \text { Populasi } \\
\mathrm{e}= & \text { Persen kelonggaran ketidaktelitian } \\
& \text { karena kesalahan penarikan sampel } \\
& \text { yang masih dapat ditolerir atau } \\
& \text { diinginkan, dalam penelitian ini } \\
& \text { adalah sebesar } 0,1
\end{aligned}
$$

maka,

$$
\begin{aligned}
& n=\frac{744.350+210.245}{1+(744.350+210.245)(0,1)^{2}} \\
& =\frac{954.595}{9.546,95} \\
& =99,989
\end{aligned}
$$

Setelah dilakukan perhitungan besar sampel diperoleh sampel minimal sebesar 99,989 orang. Sehingga dibulatkan besar sampel minimal secara keseluruhan adalah 100 orang. Responden yang bersedia mengikuti survey online secara sukarela sebanyak 185 responden. Instrumen yang digunakan dalam penelitian ini adalah kuesioner yang disebarkan secara online kepada masyarakat. Hal ini dikarenakan penelitian ini dilaksanakan pada saat kebijakan PPKM lokal sedang berlangsung di wilayah Kota Madiun dan Kabupaten Madiun sehingga tidak memungkinkan bagi

\begin{tabular}{|c|c|c|c|c|c|}
\hline $\begin{array}{c}\text { Karakteristik } \\
\text { Responden }\end{array}$ & Kategori & Jumlah & Total & $\%$ & $\begin{array}{c}\text { Total } \\
(\%)\end{array}$ \\
\hline \multirow[t]{3}{*}{ Usia } & Remaja (>18 th) & 1 & \multirow{18}{*}{185} & 0,5 & \multirow{18}{*}{100} \\
\hline & Dewasa $(18-<60$ th $)$ & 180 & & 2,2 & \\
\hline & Lansia ( $\geq 60$ th) & 4 & & 97,3 & \\
\hline \multirow[t]{2}{*}{ Jenis kelamin } & Pria & 52 & & 28,1 & \\
\hline & Wanita & 133 & & 71,9 & \\
\hline \multirow[t]{3}{*}{ Status pernikahan } & Single & 81 & & 43,8 & \\
\hline & Menikah & 94 & & 50,8 & \\
\hline & Janda/Dua & 10 & & 5,4 & \\
\hline \multirow[t]{3}{*}{ Pekerjaan } & Tidak Bekerja & 15 & & 8,1 & \\
\hline & Bekerja & 110 & & 59,5 & \\
\hline & Pelajar/ Mahasiswa & 60 & & 32,4 & \\
\hline \multirow[t]{5}{*}{ Pendidikan } & Tidak sekolah & 1 & & 0,5 & \\
\hline & SD & 2 & & 1,1 & \\
\hline & SMP & 3 & & 1,6 & \\
\hline & SMU & 79 & & 42,7 & \\
\hline & $\mathrm{PT}$ & 100 & & 54,1 & \\
\hline \multirow[t]{2}{*}{ Wilayah tempat tinggal } & Kota & 76 & & 41 & \\
\hline & Kabupaten & 109 & & 59 & \\
\hline
\end{tabular}
peneliti untuk melakukan wawancara secara langsung kepada masyarakat. Uji statistic yang digunakan pada penelitian ini yaitu uji $C h i$ Square dimana jika nilai $\mathrm{p}<0,05$ maka $\mathrm{H} 0$ ditolak dan chi square hitung > chi square tabel maka H0 ditolak.

\section{Hasil}

\section{Karakteristik Responden}

Tabel 1. Karakteristik Responden Penelitian

Berdasarkan tabel 1, dapat diketahui dari 185 responden yang menjadi sampel dalam penelitian ini mayoritas berusia, berjenis kelamin perempuan $(71,9 \%)$, telah menikah
$(50,8 \%)$, bekerja $(59,5 \%)$, memiliki pendidikan terakhir perguruan tinggi $(54,1 \%)$, dan tinggal di wilayah Kabupaten Madiun (59\%). 


\section{Pengaruh Riwayat Komorbid Terhadap Praktik 5M}

\begin{tabular}{|c|c|c|c|}
\hline Tabel & $\begin{array}{l}\text { Pengaruh } \\
\text { Terhadap }\end{array}$ & $\begin{array}{r}\text { Riwayat } \\
\text { raktik 5M }\end{array}$ & Komorbid \\
\hline \multirow{3}{*}{$\begin{array}{l}\text { Praktik } \\
\text { 5M }\end{array}$} & Riwayat & Komorbid & Total \\
\hline & $\begin{array}{l}\text { (dalam } \\
\text { terakhir) }\end{array}$ & 3 bulan & \\
\hline & Ada & Tidak Ada & \\
\hline Buruk & 6 & 48 & 54 \\
\hline Baik & 47 & 84 & 131 \\
\hline Total & 53 & 132 & 185 \\
\hline
\end{tabular}

Berdasarkan penelitian yang dilakukan terhadap 185 responden di Madiun, dapat diketahui bahwa responden yang memiliki riwayat penyakit penyerta/komorbid dalam 3 bulan terakhir adalah sebanyak 53 responden. Diantaranya, 47 responden atau 88,7 \% telah mempraktikan protokol kesehatan $5 \mathrm{M}$ dengan baik. Sedangkan sisanya, hanya sebanyak 6 responden atau $11,3 \%$ yang buruk dalam mempraktikan protokol kesehatan $5 \mathrm{M}$. Dari hasil uji statistik, diperoleh nilai $\mathrm{p}=0,001$ dan chi square hitung $=11,474$ dimana df adalah 1 dan $\alpha=0,1$ maka chi square tabel $=2,706$. Sehingga nilai $\mathrm{p}<0,05$ dan chi square hitung $>$ chi square tabel, hal ini berarti H0 ditolak. Berdasarkan uji chi square dapat disimpulkan bahwa terdapat pengaruh riwayat komorbid terhadap praktik $5 \mathrm{M}$ pada masyarakat madiun.

\section{Pengaruh Pengetahuan Tentang Covid-19 Terhadap Praktik 5M}

Tabel 3. Pengaruh Pengetahuan Tentang Covid-19 Terhadap Praktik 5M

\begin{tabular}{lccc}
\hline $\begin{array}{l}\text { Praktik } \\
\text { 5M }\end{array}$ & \multicolumn{2}{c}{$\begin{array}{c}\text { Pengetahuan Tentang } \\
\text { Penyakit Covid-19 } \\
\text { Buruk }\end{array}$} & Total \\
Buruk & 24 & 30 & 54 \\
Baik & 15 & 116 & 131 \\
Total & 39 & 146 & 185 \\
\hline
\end{tabular}

Berdasarkan penelitian terhadap 185 responden di Madiun, diperoleh hasil bahwa responden dengan pengetahuan yang baik tentang penyakit Covid-19 lebih banyak yang mempraktikan protokol kesehatan 5M dengan baik, yaitu 116 responden dari 146 responden atau $79,5 \%$. Sedangkan responden dengan pengetahuan yang buruk tentang penyakit Covid-19 lebih banyak yang buruk dalam mempraktikan protokol kesehatan 5M, yaitu 24 responden dari 39 responden atau 61,5\%. Berdasarkan hasil uji statistik diperoleh nilai $\mathrm{p}$ $=0,000$ dan chi square hitung $=25,020$ dimana $\mathrm{df}=1$ dan $\alpha=0,1$ maka chi square tabel $=$ 2,706. Dengan demikian berarti nilai $\mathrm{p}<0,05$ dan chi square hitung > chi square tabel. Hal ini berarti terdapat pengaruh pengetahuan tentang penyakit Covid-19 terhadap praktik 5M pada masyarakat Madiun.

\section{Pembahasan}

\section{Pengaruh Riwayat Komorbid Terhadap Praktik 5M}

Pandemi COVID-19 tidak hanya mengancam kesehatan fisik, akan tetapi juga kesehatan psikologis pada masyarakat. Efek psikologis yang ditimbulkan dapat berdampak ringan hingga berat. Kecemasan merupakan salah satu dampak psikologis yang kerap dialami masyarakat dalam menghadapi pandemi. Akan tetapi kecemasan dapat pula menjadi motivasi seseorang dalam upaya memproteksi dirinya dari penularan penyakit COVID-19. Motivasi merupakan salah satu faktor yang mendorong seseorang patuh terhadap protokol kesehatan. Sebagaimana penelitian yang dilakukan oleh Afrianti dan Rahmiati pada tahun 2021 yang menemukan bahwa faktor motivasi pada diri seseorang mempengaruhi kepatuhannya pada protokol kesehatan ${ }^{8}$. Hal ini karena seseorang yang mengalami kecemasan akan merasa khawatir dirinya jika dirinya tertular dan mengalami dampak yang buruk akibat penyakit tersebut. Penelitian yang dilakukan oleh Puspita, dkk (2021) kepada remaja putri di Surabaya pada tahun 2021, diperoleh hasil bahwa sebagian besar responden yaitu $98,9 \%$ mengalami kecemasan dengan berbagai level tingkatan, sehingga sebagian besar dari responden tersebut patuh terhadap kebiasaan baru di masa New Normal antara lain dengan selalu melakukan cuci tangan $(61,1 \%)$, selalu menggunakan masker $(86,3 \%)$, selalu 
menerapkan sosial distancing $(50,5 \%)$, dan tinggal di rumah sebanyak $(55,8 \%)^{8}$.

Terdapat banyak faktor yang dapat menyebabkan kecemasan pada diri seseorang dalam menghadapi pandemi, antara lain karena memiliki penyakit penyerta/komorbid. Penyakit komorbid merupakan masalah yang perlu mendapatkan perhatian yang serius selama masa pandemi. Hal ini karena penderita penyakit komorbid rentan terhadap penularan COVID-19 dan dapat menunjukkan manifestasi yang lebih parah dibandingkan orang tanpa penyakit bawaan ${ }^{9}$. Sehingga menjadi hal yang wajar jika seseorang dengan penyakit komorbid memiliki tingkat kecemasan yang lebih tinggi dalam menghadapi masa pandemi dibandingkan dengan orang tanpa penyakit penyerta/komorbid. Tobing dan Wulandari (2021) dalam penelitiannya kepada lansia dengan penyakit komorbid seperti jantung, hipertensi dan DM di Kecamatan Parongpong Bandung Barat, memperoleh kesimpulan bahwa tingkat kecemasan yang dialami oleh lansia dengan penyakit penyerta/komorbid adalah berat sekali dengan skala tingkat kecemasan 30.35. Lebih lanjut, dijelaskan dalam penelitian tersebut bahwa lansia penderita hipertensi mengalami tingkat kecemasan berat sekali dengan skala tingkat kecemasan 31.43, lansia penderita penyakit jantung mengalami tingkat kecemasan berat dengan skala tingkat kecemasan 29.41, dan lansia penderita penyakit DM mengalami tingkat kecemasan berat dengan skala tingkat kecemasan $29.67^{7}$.

Berdasarkan hasil penelitian ini, dapat disimpulkan bahwa seseorang dengan riwayat penyakit penyerta/komorbid cenderung lebih cemas dalam menghadapi pandemi sehingga termotivasi untuk lebih patuh/lebih baik dalam mempraktikan protokol kesehatan $(5 \mathrm{M})$ yaitu mencuci tangan, memakai masker, menjaga jarak, menjauhi kerumunan dan menjaga imunitas. Dengan kata lain, seseorang yang memiliki riwayat komorbid akan memiliki kesadaran yang lebih baik dalam memproteksi dirinya dibandingkan dengan seseorang yang tidak memiliki penyakit penyerta.

Pada penelitian ini juga diketahui bahwa lebih dari separuh responden yang tidak memiliki penyakit penyerta juga telah melaksanakan protokol kesehatan $5 \mathrm{M}$ dengan baik yaitu sebesar 84 responden dari 132 responden atau $63,6 \%$. Hal ini karena mayoritas masyarakat Madiun yang menjadi sampel dalam penelitian ini, baik yang memiliki riwayat komorbid maupun yang tidak memiliki riwayat komorbid telah memiliki pengetahuan yang baik tentang COVID-19. Sehingga terbentuk kesadaran yang baik pula pada diri mereka untuk memproteksi diri dari penularan COVID-19 meskipun dirinya tidak memiliki penyakit penyerta.

\section{Pengaruh Pengetahuan Tentang Covid-19 Terhadap Praktik 5M}

Pengetahuan merupakan salah satu domain dari perilaku kesehatan termasuk perilaku pencegahan terhadap suatu penyakit. Afrianti (2021) dalam penelitiannya menemukan bahwa salah satu faktor yang mempengaruhi kepatuhan masyarakat terhadap protokol kesehatan COVID-19 adalah pengetahuan dengan nilai $\mathrm{p}=0,015^{10}$. Pada penelitian lain yang dilakukan oleh Dewi (2020) menemukan bahwa faktor tingkat pengetahuan merupakan faktor karakteristik pada individu yang berpengaruh terhadap perilaku pencegahan penularan COVID-19 dibandingkan dengan faktor lain seperti usia, tingkat pendidikan, pekerjaan, dan sosial ekonomi ${ }^{11}$. Hal tersebut sejalan dengan penelitian ini yang menemukan bahwa pengetahuan merupakan faktor yang berpengaruh terhadap praktik $5 \mathrm{M}$ pada masyarakat Madiun. Berdasarkan hasil penelitian, dapat diketahui bahwa lebih dari separuh atau $78,9 \%$ responden yang menjadi sampel dalam penelitian ini memiliki pengetahuan yang baik tentang penyakit COVID-19. Dan dapat diketahui pula, bahwa lebih dari separuh atau $70,8 \%$ responden yang menjadi sampel dalam penelitian ini telah melaksanakan protokol kesehatan $5 \mathrm{M}$ dengan baik. Hal ini menunjukkan bahwa faktor pengetahuan mampu mendorong seseorang untuk lebih patuh dalam menjalankan protokol kesehatan. Karena seseorang dengan pengetahuan yang baik akan memiliki kesadaran yang lebih baik pula tentang pentingnya menjaga kesehatan. 
Pengetahuan yang baik pada masyarakat tentang kesehatan dipengaruhi oleh berbagai faktor. Wulandari dkk (2020) menyimpulkan dalam penelitiannya bahwa karakteristik individu seperti pendidikan, usia, status pekerjaan, dan posisi seseorang dalam keluarga memiliki hubungan dengan pengetahuan tentang COVID-19. Sedangkan jenis kelamin tidak berhubungan dengan pengetahuan seseorang tentang COVID-19 ${ }^{12}$.

Dalam penelitian ini, sebagian besar responden yang menjadi sampel penelitian adalah perempuan. Individu dengan jenis kelamin perempuan biasanya lebih mudah khawatir dan cemas dibandingkan dengan lakilaki. Sehingga hal ini mendorong mereka untuk mencari tahu lebih banyak tentang penyakit COVID-19. Mayoritas responden yang menjadi sampel dalam penelitian ini adalah pekerja dengan pendidikan terakhir adalah perguruan tinggi. Seseorang yang bekerja cenderung untuk lebih berhati-hati dalam menjaga dirinya dari penularan COVID-19 karena lebih sering melakukan kontak dengan orang lain daripada seseorang yang tidak bekerja sehingga risiko untuk tertular COVID-19 lebih besar pada mereka yang bekerja. Hal ini mendorong mereka untuk mencari informasi tentang penyakit COVID-19.

Seseorang dengan tingkat pendidikan yang tinggi cenderung lebih kritis dan mudah menerima informasi sehingga memiliki tingkat pengetahuan yang relatif lebih baik dibandingkan dengan individu dengan latar belakang pendidikan yang rendah. Individu yang telah berkeluarga cenderung akan lebih berhati-hati dan mengutamakan keselamatan diri karena merasa memiliki tanggungjawab terhadap keluarganya, sehingga cenderung lebih patuh terhadap protokol kesehatan. Hal ini pula yang mendorong mereka untuk mencari informasi terkait dengan COVID-19 dan bagaimana cara mencegah penularannya.

Kekurangan dalam penelitian ini adalah hanya membatasi penelitian pada faktor riwayat komorbid dan pengetahuan dalam mempengaruhi praktik $5 \mathrm{M}$ pada masyarakat. Padahal terdapat banyak sekali faktor lain yang mungkin menjadi penyebab mengapa masyarakat patuh dalam melaksanakan protokol kesehatan. Hal ini disebabkan karena keterbatasan peneliti, sehingga hasil dari penelitian ini diharapkan dapat menjadi dasar untuk dilakukannya penelitian lanjutan yang lebih mendalam selain sebagai masukan bagi pemerintah Kota dan Kabupaten Madiun dalam menetapkan kebijakan kesehatan khususnya untuk mencegah penularan COVID-19 di wilayah kerjanya.

\section{Kesimpulan}

Dari penelitian ini dapat disimpulkan :

1. Terdapat pengaruh riwayat komorbid terhadap praktik $5 \mathrm{M}$ pada masyarakat Madiun tahun 2020.

2. Terdapat pengaruh pengetahuan tentang penyakit COVID-19 terhadap praktik 5M pada masyarakat Madiun tahun 2020.

\section{Ucapan Terima Kasih}

Terima kasih penulis ucapkan kepada semua pihak yang telah membantu dalam penelitian ini khususnya LPPM UNIPMA yang telah memberikan ijin kepada penulis untuk melaksanakan penelitian, Pemerintah Kota dan Kabupaten Madiun dan pihak terkait lain yang telah membantu terselesaikannya penelitian ini dan tidak bisa penulis sebutkan satu-persatu.

\section{Daftar Pustaka}

1. Indonesia KKR. 2020. Analisis Data COVID-19 Indonesia. Jakarta. [cited 2020 Sep 1]. Available from: https://covid19. go.id/p/berita/analisis-data-covid-19indonesia-update-per-30-agustus-2020.

2. Syakurah R., Moudy J. 2020. Pengetahuan terkait Usaha Pencegahan Coronavirus Disease (COVID-19) di Indonesia. HIGEIA Journal Public Health Research and Development 4(3). Available from: https://journal.unnes.ac.id/sju/index.php/hi geia/issue/view/1834.

3. Aji, Binar, Devy SR. 2006. Faktor Predisposing, Enabling dan Reinforcing pada Pasien di Pengobatan Alternatif 
Radiesthesi Medik Metode Romo $\mathrm{H}$. Loogman di Purworejo Jawa Tengah. The Indonesia Journal of Public Health. 3(2) : 35-44. Available from: https://media. neliti.com/media/publications/3863-IDfaktor-predisposing-enabling-danreinforcing-pada-pasien-di-pengobatanalternati.pdf.

4. Amalia R. 2021. Hubungan Pengetahuan Dan Tindakan Masyarakat Terhadap 5M Pada Masa Pandemi Di Kelurahan Kuin Utara Banjarmasin Utara Tahun 2021. Diploma Thesis. Universitas Islam Kalimantan.

5. Iit, Katarina., Yuliana ND. 2021. Hubungan Pengetahuan Lansia Tentang Covid-19 Dengan Perilaku 5 M Di Posyandu Lansia Melati Wilayah Kerja Puskesmas Kampung Bali Tahun 2021. Jurnal Kebidanan. 11(2):630-636.

6. Osibogun A, Balogun M, Abayomi A, Idris J, Kuyinu Y, Odukoya $\mathrm{O}$ et al. Outcomes of COVID-19 patients with comorbidities in southwest Nigeria. 2021. PLoS One. 16(3):e0248281. Available from:https://journals.plos.org/plosone/artic le?id=10.1371/journal.pone.0248281.

7. Tobing CPRL, Wulandari ISM. 2021. Tingkat Kecemasan Bagi Lansia Yang Memiliki Penyakit Penyerta Ditengah Situasi Pandemik Covid-19 Di Kecamatan Parongpong, Bandung Barat. Community of Publishing In Nursing. 9(2):135-142. Available from: file:///C:/Users/INTEL/ Downloads/71693-457-209848-1-1020210 502.pdf.

8. Novi Afrianti. CR. 2021. Faktor-Faktor Yang Mempengaruhi Kepatuhan Masyarakat Terhadap Protokol Kesehatan Covid-19. Jurnal Ilmiah Permas: Jurnal Ilmiah STIKES Kendal. 11(1):113-124. Available from:http://journal.stikeskendal. ac.id/index.php/PSKM/article/view/1045/ 647.
9. Puspita, Maya I, Rozifah, Wigati A, Nadhiroh, Maatun A. 2021. Gambaran Kecemasan Dan Kepatuhan Remaja Putri Terhadap Kebiasaan Baru Pada Masa Pandemi Covid-19 di Surabaya. JOMIS. 5(1):52-61. Available from: http://jurnal.univrab.ac.id/index.php/jomis/ article/view/1492/938.

10. Fadhilah N, Nurul P, Subekti, Tri R, Tri Y. 2021. Kepatuhan Penderita Hipertensi Menjalankan Protokol Kesehatan Covid19 Dipengaruhi Oleh Tingkat Pengetahuan. Jurnal Stikes Kendal. 13(3):779-790. Available from: http://journal.stikeskendal.ac.id/index.php/ Keperawatan/article/view/1758/1043.

11. Dewi, Untari E. 2020. Faktor-Faktor Yang Mempengaruhi Perilaku Masyarakat Dalam Pencegahan Penularan Covid-19. Jurnal Keperawatan Sekolah Tinggi Ilmu Kesehatan William Booth. 9(2):21-25. Available from:http://jurnal.stikeswilliam booth.ac.id/index.php/Kep/article/view/ 259.

12. Wulandari. 2020. Hubungan Karakteristik Individu Dengan Pengetahuan Tentang Pencegahan Corona virus Disease 2019 Pada Masyarakat di Kalimantan Selatan. Jurnal Kesehatan Masyarakat Indonesia. 15(1). Available from:https://jurnal. unimus.ac.id/index.php/jkmi/article/view/5 837. 